\title{
Relationship of RNA/DNA ratio and temperature to growth in larvae of Atlantic cod Gadus morhua
}

\author{
Elaine M. Caldarone ${ }^{1, *}$, Jeanne M. St. Onge-Burns ${ }^{1}$, Lawrence J. Buckley ${ }^{2}$ \\ ${ }^{1}$ National Oceanic and Atmospheric Administration National Marine Fisheries Service, Northeast Fisheries Science Center, \\ Narragansett Laboratory, 28 Tarzwell Drive, Narragansett, Rhode Island 02882-1199, USA \\ ${ }^{2}$ URI/NOAA CMER Program, Graduate School of Oceanography, University of Rhode Island, Narragansett, \\ Rhode Island 02882, USA
}

\begin{abstract}
The RNA, DNA, and protein content of larval cod Gadus morhua reared in the laboratory at 3 temperatures and 3 densities of prey was measured. The data were used to define a quantitative relationship between RNA/DNA ratio (R/D), water temperature $(T)$, and protein-specific growth rate $\left(\mathrm{SGR}, \% \mathrm{~d}^{-1}\right)$. The nucleic acid content of each larva was determined with both a 2-dye flow-injection fluorometric assay (FIA) and a 1-dye/1-enzyme fluorometric microplate assay (MFA) in order to calibrate each methodology. The resulting equations were: SGR $=3.65 \mathrm{R} / \mathrm{D}+1.02 \mathrm{~T}-13.05$ for FIA, and SGR $=4.03 \mathrm{R} / \mathrm{D}+0.88 \mathrm{~T}-11.16$ for MFA. Measured growth rates ranged from negative $\left(-8 \% \mathrm{~d}^{-1}\right)$ to $20 \% \mathrm{~d}^{-1}$. Water temperature and larval R/D explained 37 to $39 \%$ of the variability in the observed growth rate. The models are applicable over temperatures ranging from 2.5 to $9.5^{\circ} \mathrm{C}$ and can be used to determine short-term growth rates of cod larvae collected from both the laboratory and field.
\end{abstract}

KEY WORDS: RNA/DNA ratio $\cdot$ Growth $\cdot$ Cod $\cdot$ Larvae $\cdot$ Temperature effects Resale or republication not permitted without written consent of the publisher

\section{INTRODUCTION}

Temperate marine fishes experience a high rate of mortality during their first few months of life. Predation, starvation, and physical processes leading to unfavorable dispersal can all contribute to this outcome (Houde 1987). Poor nutritional condition of larvae not only contributes to an increase in mortality rates through starvation, but can lead to an increase in predation mortality rates through diminished escape responses or increased duration of the larval stage (Houde 1987, Meekan \& Fortier 1996). Even small changes in stage duration, mortality rates, or growth rates in the early life of marine fishes may result in significant variability in recruitment potential (Houde 1987). There is general agreement that accurate estimates of the nutritional condition, growth rate, and their variability in fieldcaught larval fishes could help identify factors that regulate survival and determine recruitment success (Houde 1987, Westerman \& Holt 1994, Folkvord et al. 1996, Meekan \& Fortier 1996). In both laboratory and field applications, the ratio of RNA to DNA (R/D) is a widely used index of recent growth and nutritional condition in larval fishes (e.g. Buckley \& Lough 1987, Robinson \& Ware 1988, Canino et al. 1991, Malloy \& Targett 1994a, Folkvord et al. 1996, Clemmesen et al. 1997, Rooker et al. 1997, Chícharo 1998, Heyer et al. 2001). The physiological basis for this index is that RNA, which consists of ribosomal RNA (75 to $94 \%$ of total RNA), messenger RNA, and transfer RNA, is an essential cellular component in the biosynthesis of proteins (Young 1970). The number and activity of the ribosomes fluctuate in response to food availability and the demand for protein synthesis and growth (Henshaw et al. 1971). In contrast, the amount of DNA remains relatively constant during periods of starvation (Bulow 1987). After initiation of feeding, R/D has been shown to reflect changes in the nutritional condition and growth rate of a larva over periods as short as 1 to $4 \mathrm{~d}$ (Buckley 1980, Wright \& Martin 1985, Clemmesen 1987, Westerman \& Holt 1994). This quick response time makes it possible to examine linkages between environmental conditions in the field and variability in larval nutritional condition. 
Researchers have observed a direct linear relationship between R/D, temperature, and growth in laboratory-reared larval winter flounder Pseudopleuronectes americanus (Buckley 1982), and sand lance Ammodytes americanus (Buckley et al. 1984), mesocosmreared larval herring Clupea harengus (Folkvord et al. 1996), and field-caught juvenile summer flounder Paralichthys dentatus (Malloy \& Targett 1994b). Within a narrow temperature range $\left(1\right.$ to $\left.2^{\circ} \mathrm{C}\right), \mathrm{R} / \mathrm{D}$ from individual larval fishes can be directly compared and the relative nutritional condition of the fishes inferred. Over broader temperature ranges $\left(>2^{\circ} \mathrm{C}\right)$, adjustments must be made for temperature since the activity of rRNA increases with temperature (Buckley et al. 1999). In these situations, models relating R/D, temperature, and growth are of benefit. Using data from 8 species of temperate marine fishes reared at a variety of feeding conditions and temperatures $\left(2\right.$ to $\left.20^{\circ} \mathrm{C}\right)$, Buckley (1984) developed a generalized R/D-temperaturegrowth model based on nucleic acid concentrations determined with an ultraviolet-light (UV) absorption assay. In recent years, researchers have more commonly used spectrofluorometric methods for analysis of nucleic acids in larval fishes. These techniques are as precise as the UV method, but more rapid and sensitive. Even the smallest individual fish larva $(\sim 10 \mu \mathrm{g}$ dry weight) can be analyzed with fluorometric methods, while the UV assay requires a minimum sample size of $\sim 600 \mu \mathrm{g}$ dry weight (Buckley \& Bulow 1987).

Due to differences in analytical procedures and estimated RNA and DNA content, ratios determined with fluorometric procedures cannot be directly substituted into Buckley's UV-based growth model (Caldarone et al. 2001). In this study, the relationship between $\mathrm{R} / \mathrm{D}$, temperature, and growth in larvae of laboratoryreared cod Gadus morhua was calibrated based on nucleic acids levels determined with 2 different fluorometric assays, both of which have been routinely used in our laboratory: a 2-dye flow-injection assay and a 1-dye/1-enzyme microplate assay. The models generated can be used to estimate recent growth of larvae collected in both the laboratory and field, and will be used in future studies to estimate recent growth of cod and haddock larvae collected during a multi-year field sampling effort on Georges Bank (US Global Ocean Ecosystems Dynamics [GLOBEC] program).

\section{MATERIALS AND METHODS}

Growth trials. Experiments were conducted using eggs and larvae spawned by NOAA/NMFS Narragansett Laboratory Gadus morhua broodstock. The broodstock, which consisted of 25 to 40 fish caught by longline on the western side of the Great South Chan- nel, Massachusetts, USA, were maintained in a large community tank for up to $10 \mathrm{yr}$ and induced to spawn by photothermal manipulation (Buckley et al. 2000).

We conducted 2 experiments of similar design in 1995 and 1997. Larvae were reared for 5 to $8 \mathrm{wk}$ in six 381 black all-glass rectangular aquaria in each of 3 identical constant temperature rooms (18 tanks in total). To incorporate the range of temperatures routinely encountered by larval cod on Georges Bank, room temperatures were set at 3,6 and $9^{\circ} \mathrm{C}$. To produce a range of growth rates, 3 feeding treatments were used at each temperature. Prey densities in each tank were adjusted 5 to 7 times per week based on the mean count of triplicate $3 \mathrm{ml}$ samples from each aquarium, and 2 to 3 times per week, $30 \%$ of the water in each aquarium was replaced and the tank bottoms were siphoned. Cultured micro-algae Tetraselmis spp. was added at each water change. Salinities ranged from 31 to $33 \mathrm{ppt}$ and the photoirradiance at the water surface was 13 to $19 \mu \mathrm{mol} \mathrm{s}{ }^{-1} \mathrm{~m}^{-2}$ during a $12 \mathrm{~h}$ photoperiod. Water temperatures were monitored daily and the water in the aquaria was gently aerated to aid the even dispersion of prey.

The first trial used a $3 \times 3$ factorial design with duplicate tanks at each combination of temperature and prey level for a total of 18 tanks. In late January 1995, $60 \mathrm{ml}$ of fertilized eggs ( 18000 eggs) were collected and incubated at $6^{\circ} \mathrm{C}$ for $4 \mathrm{~d}$. The eggs were then divided into 3 groups, acclimated to the rearing temperatures for $24 \mathrm{~h}$, and distributed among the tanks. Each tank received $2 \mathrm{ml}$ of eggs, resulting in an initial stocking density of $\sim 600$ eggs. Approximately $50 \%$ hatch occurred 13, 17 and $21 \mathrm{~d}$ after fertilization at 9,6 and $3^{\circ} \mathrm{C}$ respectively. Larvae were fed wild zooplankton (primarily copepod nauplii and copepodites) at a concentration of $0.1,0.2$ or 0.5 plankters $\mathrm{ml}^{-1}$. The plankton was collected $6 \mathrm{~d}$ per week from Narragansett Bay and sieved by size before being used as prey. Plankters of 64-210, 210-333 and 333-452 $\mu \mathrm{m}$ size were fed to $0-3,3-5$ and $>5$ wk old larvae, respectively. By $38 \mathrm{~d}$ posthatch (dph), due to a combination of mortality and sampling, the numbers of remaining larvae were not sufficient to permit further sampling and the experiment was concluded.

The second trial included a starvation treatment and used a similar $3 \times 3$ factorial design with duplicate tanks at each combination of temperature and prey level. In late January 1997, $70 \mathrm{ml}$ of fertilized eggs were collected and incubated at $6^{\circ} \mathrm{C}$ until hatch $(14 \mathrm{~d})$; $1 \mathrm{dph}$ larvae were individually counted and randomly distributed into the 18 aquaria described previously, resulting in initial stocking densities of 650 larvae per tank. Room temperatures, which were initially set at $6^{\circ} \mathrm{C}$, were gradually increased or decreased over a 
period of $24 \mathrm{~h}$ until they reached nominal levels of 3 , 6 and $9^{\circ} \mathrm{C}$. Larvae were either starved or fed with rotifers Brachionus plicatilis at a concentration of 4 or $8 \mathrm{ml}^{-1}$. Rotifers were raised on algae Tetraselmis spp. and enriched with a lipid/vitamin mixture (Super Selco, Inve) $6 \mathrm{~h}$ prior to feeding. At $16 \mathrm{dph}$, the 4 and $8 \mathrm{ml}^{-1}$ rotifer diets were supplemented with SuperSelco-enriched brine shrimp Artemia sp. nauplii at a concentration of 0.25 and $0.5 \mathrm{ml}^{-1}$ respectively. At $55 \mathrm{dph}$, due to a combination of mortality and sampling, the numbers of remaining larvae were not sufficient to warrant further sampling and the experiment was terminated.

Biochemical parameters. For both trials, larvae were sampled from each tank every $4 \mathrm{~d}$, starting at $2 \mathrm{dph}$ (5 larvae per sample from the wild-plankton diet group, 10 larvae per sample from both the starved and rotifer-fed groups). Each larva was immediately videotaped and individually frozen in a cryovial at $-80^{\circ} \mathrm{C}$. Lengths were estimated to the nearest $0.01 \mathrm{~mm}$ from the video images using video image-analysis software (Optimas). On the day of analysis, each frozen larva was extracted in 1\% N-lauroylsarcosine to dissociate the nucleoproteins. Aliquots from the resulting homogenate were measured for RNA, DNA, and protein content. The nucleic acids were determined with both a 2-dye (Hoechst 33258, ethidium bromide [EB]) fluorometric flow-injection analysis (FIA) assay (Caldarone \& Buckley 1991) and a 1-dye/1 enzyme (EB plus RNase) 96-well microplate fluorometric assay (MFA) (Caldarone et al. 2001).

In the FIA system, a sample is injected into a reagent stream containing one of the fluorochrome dyes. The injected sample is mixed and transported with the reagent to the detector, which continuously records the fluorescence. The sample fluorescence is displayed as a peak whose area is proportional to the concentration. DNA values are determined from the sample fluorescence in Hoechst 33258, while RNA values are determined by subtracting the DNA-EB fluorescence from the total EB fluorescence. For this study, the Hoechst working reagent in the FIA method was modified to contain $0.1 \mathrm{~N} \mathrm{NaCl}$ and $25 \mu \mathrm{g} \mathrm{l}^{-1}$ Hoechst 33258 at a $\mathrm{pH}$ of 7 .

The MFA method is described in detail in Caldarone et al. (2001). Briefly, the standards and Nlauroylsarcosine-extracted samples are mixed with EB in a 96-well microplate. Total fluorescence in a sample is measured first. RNA is then enzymatically digested by the addition of RNase, and the RNA values are determined by subtraction after a second reading. DNA values are determined from the fluorescence remaining after the RNase treatment. An additional step of enzymatic digestion with DNase was eliminated when it was verified that the result- ing fluorescence values were equal to the blanks. In both methods, serial dilutions of commercial preparations of $18 \mathrm{~S}$ and $28 \mathrm{~S}$ rRNA (USB, Sigma) and ultrapure highly polymerized calf thymus DNA (Hoefer, Sigma) were used to construct standard calibration curves. Standard rRNA concentrations ranged from 0.43 to $6.30 \mu \mathrm{g} \mathrm{ml} \mathrm{m}^{-1}$. DNA standards ranged from 0.12 to $1.37 \mu \mathrm{g} \mathrm{ml} \mathrm{m}^{-1}$.

Larval protein content was determined on duplicate aliquots of extract with a bicinchoninic colorimetric assay (Smith et al. 1985) adapted to a 96-well microplate format. Samples or standards plus reagents were incubated at $60^{\circ} \mathrm{C}$ for $1 \mathrm{~h}$ to allow for complete color development. A dilution series of bovine serum albumin was used to construct a standard calibration curve.

A control homogenate was prepared by homogenizing 100 cod larvae $(21 \mathrm{dph})$ in $7.5 \mathrm{ml}$ distilled deionized water with an Ultra-turrax tissumizer equipped with a micro attachment. $75 \mu$ aliquots of the homogenate were stored frozen at $-80^{\circ} \mathrm{C}$ and, as a quality control measure, 1 aliquot was processed during each nucleicacid assay and protein assay to verify the accuracy of the runs.

Larval growth. The instantaneous protein growth coefficient $\left(G_{i} \mathrm{~d}^{-1}\right)$ was calculated over the $4 \mathrm{~d}$ sampling interval using the formula:

$$
G_{i}=\frac{\ln P_{t}-\ln P_{t-4}}{4}
$$

where $P_{t}$ is the mean protein content $(\mu \mathrm{g})$ of larvae from 1 tank (nominally 5 or 10 individuals depending upon the trial) at time $t$, and $t$ is age in days. Proteinspecific growth rates expressed as \% $\mathrm{d}^{-1}$ (SGR) were calculated using the formula $\mathrm{SGR}=100 \times\left(\mathrm{e}^{G i}-1\right)$ (Houde \& Schekter 1981).

Statistical analyses. Using data from all the individuals sampled, a Pearson product moment correlation matrix was computed to test the strength of the relationship between the variables measured (length, RNA content, DNA content, protein content, age, water temperature, R/D, protein/DNA, and SGR).

Using data from all trials combined, the relation between SGR and the independent variables was examined with multiple linear regression analysis. A maximum $\mathrm{R}^{2}$ selection process was used to obtain the best model fit. Input values included tank means of the measured parameters from an individual sampling day, mean tank temperature between sampling days, and the corresponding SGR.

The relation between nucleic acid values generated by the 2 fluorometric assays was examined with linear regression analysis. All statistical analyses were carried out using SAS statistical software (SAS Institute 1999) with a significance level set at $\mathrm{p} \leq$ 0.05 . 
Table 1. Gadus morhua. Pearson product moment correlation (r) of parameters measured in ind. cod larvae from plankton-fed, rotifer-fed, and starved treatments combined. R/D: RNA/DNA; SGR: protein-specific growth rate $\left(\% \mathrm{~d}^{-1}\right)$ calculated over $4 \mathrm{~d}$ sampling interval $;$ dph: days posthatch. Sample sizes ranged from 1346 to 1652 . Nucleic acid data are from FIA. ${ }^{*} p<0.01,{ }^{* *} p<0.0001$

\begin{tabular}{|c|c|c|c|c|c|c|c|c|}
\hline Parameter & DNA & Protein & Length & Age & Temperature & $\mathrm{R} / \mathrm{D}$ & Protein/DNA & SGR \\
\hline RNA ( $\mu$ g larva $\left.{ }^{-1}\right)$ & $0.98^{* *}$ & $0.97^{* *}$ & $0.89^{* *}$ & $0.66^{* *}$ & $0.35^{* *}$ & $0.29^{* *}$ & $0.22^{* *}$ & $0.32^{* *}$ \\
\hline DNA $\left(\mu \mathrm{g}\right.$ larva $\left.^{-1}\right)$ & & $0.98^{* *}$ & $0.90^{* *}$ & $0.70^{* *}$ & $0.38^{* *}$ & $0.23^{* *}$ & $0.19^{* *}$ & $0.30^{* *}$ \\
\hline Protein $\left(\mu \mathrm{g}\right.$ larva $\left.^{-1}\right)$ & & & $0.87^{* *}$ & $0.66^{* *}$ & $0.35^{* *}$ & $0.24^{* *}$ & $0.25^{* *}$ & $0.29 * *$ \\
\hline Length (mm) & & & & $0.80^{* *}$ & $0.41^{* *}$ & $0.39^{* *}$ & $0.30^{* *}$ & $0.47^{* *}$ \\
\hline Age (dph) & & & & & $0.21^{* *}$ & $0.11^{* *}$ & $0.13^{* *}$ & $0.29^{* *}$ \\
\hline Temperature $\left({ }^{\circ} \mathrm{C}\right)$ & & & & & & $0.07^{*}$ & -0.03 & $0.24^{* *}$ \\
\hline $\mathrm{R} / \mathrm{D}$ & & & & & & & $0.69^{* *}$ & $0.54^{* *}$ \\
\hline Protein/DNA & & & & & & & & $0.51^{* *}$ \\
\hline
\end{tabular}

Table 2. Gadus morhua. Protein-specific growth rate (SGR) of cod larvae fed with plankton or rotifers, or starved. Days posthatch (dph) values are for individual tanks. SGR values are time-averaged tank means

\begin{tabular}{|c|c|c|c|c|}
\hline $\begin{array}{l}\text { Temp. } \\
\left({ }^{\circ} \mathrm{C}\right)\end{array}$ & $\begin{array}{l}\text { Prey level } \\
\left(\text { no. } \mathrm{ml}^{-1}\right)\end{array}$ & $\begin{array}{c}\text { Tank } \\
\text { no. }\end{array}$ & $\begin{array}{c}\text { Age at last } \\
\text { sampling (dph) }\end{array}$ & $\begin{array}{c}\text { SGR } \\
\left(\% d^{-1}\right)\end{array}$ \\
\hline \multicolumn{5}{|c|}{ Wild plankton diet } \\
\hline \multirow[t]{3}{*}{$3.4 \pm 0.1$} & 0.1 & $\begin{array}{l}1 \\
2\end{array}$ & $\begin{array}{l}22 \\
22\end{array}$ & $\begin{array}{l}-0.1 \\
-0.6\end{array}$ \\
\hline & 0.2 & $\begin{array}{l}3 \\
4\end{array}$ & $\begin{array}{l}34 \\
22\end{array}$ & $\begin{array}{l}2.3 \\
2.0\end{array}$ \\
\hline & 0.5 & $\begin{array}{l}5 \\
6\end{array}$ & $\begin{array}{l}22 \\
26\end{array}$ & $\begin{array}{l}3.6 \\
3.7\end{array}$ \\
\hline \multirow[t]{3}{*}{$6.0 \pm 0.2$} & 0.1 & $\begin{array}{l}7 \\
8\end{array}$ & $\begin{array}{l}26 \\
22\end{array}$ & $\begin{array}{l}3.2 \\
1.9\end{array}$ \\
\hline & 0.2 & $\begin{array}{r}9 \\
10\end{array}$ & $\begin{array}{l}18 \\
26\end{array}$ & $\begin{array}{l}3.8 \\
3.7\end{array}$ \\
\hline & 0.5 & $\begin{array}{l}11 \\
12\end{array}$ & $\begin{array}{l}30 \\
22\end{array}$ & $\begin{array}{l}5.7 \\
5.6\end{array}$ \\
\hline \multirow[t]{3}{*}{$8.9 \pm 0.2$} & 0.1 & $\begin{array}{l}13 \\
14\end{array}$ & $\begin{array}{l}18 \\
18\end{array}$ & $\begin{array}{r}4.9 \\
11.2\end{array}$ \\
\hline & 0.2 & $\begin{array}{l}15 \\
16\end{array}$ & $\begin{array}{l}26 \\
22\end{array}$ & $\begin{array}{l}5.5 \\
7.6\end{array}$ \\
\hline & 0.5 & $\begin{array}{l}17 \\
18\end{array}$ & $\begin{array}{l}18 \\
38\end{array}$ & $\begin{array}{r}13.3 \\
7.8\end{array}$ \\
\hline \multicolumn{5}{|c|}{ Starved and rotifer diet } \\
\hline \multirow[t]{3}{*}{$2.6 \pm 0.2$} & 0 & $\begin{array}{l}14 \\
18\end{array}$ & $\begin{array}{l}18 \\
18\end{array}$ & $\begin{array}{l}-2.1 \\
-2.4\end{array}$ \\
\hline & 4 & $\begin{array}{l}15 \\
17\end{array}$ & $\begin{array}{l}30 \\
18\end{array}$ & $\begin{array}{r}0.9 \\
-2.1\end{array}$ \\
\hline & 8 & $\begin{array}{l}13 \\
16\end{array}$ & $\begin{array}{l}22 \\
30\end{array}$ & $\begin{array}{l}0.0 \\
1.4\end{array}$ \\
\hline \multirow[t]{3}{*}{$5.8 \pm 0.2$} & 0 & $\begin{array}{l}10 \\
11\end{array}$ & $\begin{array}{l}10 \\
10\end{array}$ & $\begin{array}{l}-5.3 \\
-2.7\end{array}$ \\
\hline & 4 & $\begin{array}{r}7 \\
12\end{array}$ & $\begin{array}{l}14 \\
22\end{array}$ & $\begin{array}{r}-3.7 \\
1.3\end{array}$ \\
\hline & 8 & $\begin{array}{l}8 \\
9\end{array}$ & $\begin{array}{l}18 \\
22\end{array}$ & $\begin{array}{r}-0.7 \\
2.9\end{array}$ \\
\hline \multirow[t]{3}{*}{$9.3 \pm 0.3$} & 0 & $\begin{array}{l}1 \\
2\end{array}$ & $\begin{array}{l}10 \\
10\end{array}$ & $\begin{array}{l}-7.6 \\
-5.6\end{array}$ \\
\hline & 4 & $\begin{array}{l}4 \\
6\end{array}$ & $\begin{array}{l}55 \\
14\end{array}$ & $\begin{array}{l}8.4 \\
3.7\end{array}$ \\
\hline & 8 & $\begin{array}{l}3 \\
5\end{array}$ & $\begin{array}{l}55 \\
26\end{array}$ & $\begin{array}{l}7.3 \\
6.5\end{array}$ \\
\hline
\end{tabular}

\section{RESULTS}

\section{Methodology}

The 2 fluorometric assays gave similar estimates of RNA and DNA content ( $\left.\mu \mathrm{g} \operatorname{larva}^{-1}\right)$. The relation between the 2 methods was linear and expressed by the following equations:

$$
\begin{aligned}
& \operatorname{RNA}_{(\text {FIA })}=-0.130+1.083 \operatorname{RNA}_{(\text {MFA })} R^{2}=0.996 \mathrm{n}=1360 \\
& \operatorname{DNA}_{(\text {FIA })}=0.031+0.877 \mathrm{DNA}_{(\text {MFA })} R^{2}=0.998 \mathrm{n}=1361
\end{aligned}
$$

The accuracy and precision of both methods were very similar: the $\mathrm{R}^{2} \mathrm{~S}$ of the nucleic acid calibration curves were $>0.99$; day-to-day variability (coefficient of variation) of the control homogenates ranged from 4 to $6 \%$; and recovery rates of nucleic acid spikes averaged $98 \pm 3 \%$. With the MFA, 77 samples could be analyzed in duplicate in $7 \mathrm{~h}$, while with the FIA 77 single samples were processed in $9 \mathrm{~h}$.

\section{Parameter correlations}

For brevity, only the values obtained with FIA will be presented. Results of the Pearson product moment correlation analysis indicated that all the parameters measured were positively correlated at the $\mathrm{p}<0.0001$ level with the exception of R/D vs temperature ( $\mathrm{p}=$ $0.0067)$ and protein/DNA vs temperature $(p=0.2067)$ (Table 1). In all the fed treatments, the fish generally grew larger with increasing age, temperature, and prey level, as evidenced by an overall increase in length (data not shown) and protein content ( $\mu$ g larva ${ }^{-1}$, Fig 1). In the starved group, mean protein content decreased (Fig. 1) until 100\% mortality was reached, while mean lengths (data not shown) did not change. For visual clarity, all figures contain only data from the wild zooplankton trial plus the starved group. The wild plankton and rotifer trials yielded similar results, although the time-averaged growth rates for the rotifer diet were lower (Table 2). Larval lengths 
ranged from 4.4 to $13.4 \mathrm{~mm}$ and 4.4 to $15.9 \mathrm{~mm}$ for larvae fed wild plankton and rotifers respectively.

\section{Trends in biochemical parameters with time, temperature, and feeding level}

In the starved group, mean DNA content remained nearly stable with increasing age and temperature $(\mu \mathrm{g}$ larva $^{-1}$, Fig. 2), while mean RNA content ( $\mu \mathrm{g}$ larva $^{-1}$, Fig. 3) decreased, resulting in a large decrease in R/D (Fig. 4) . Starved fish reached $100 \%$ mortality at 18, 10,
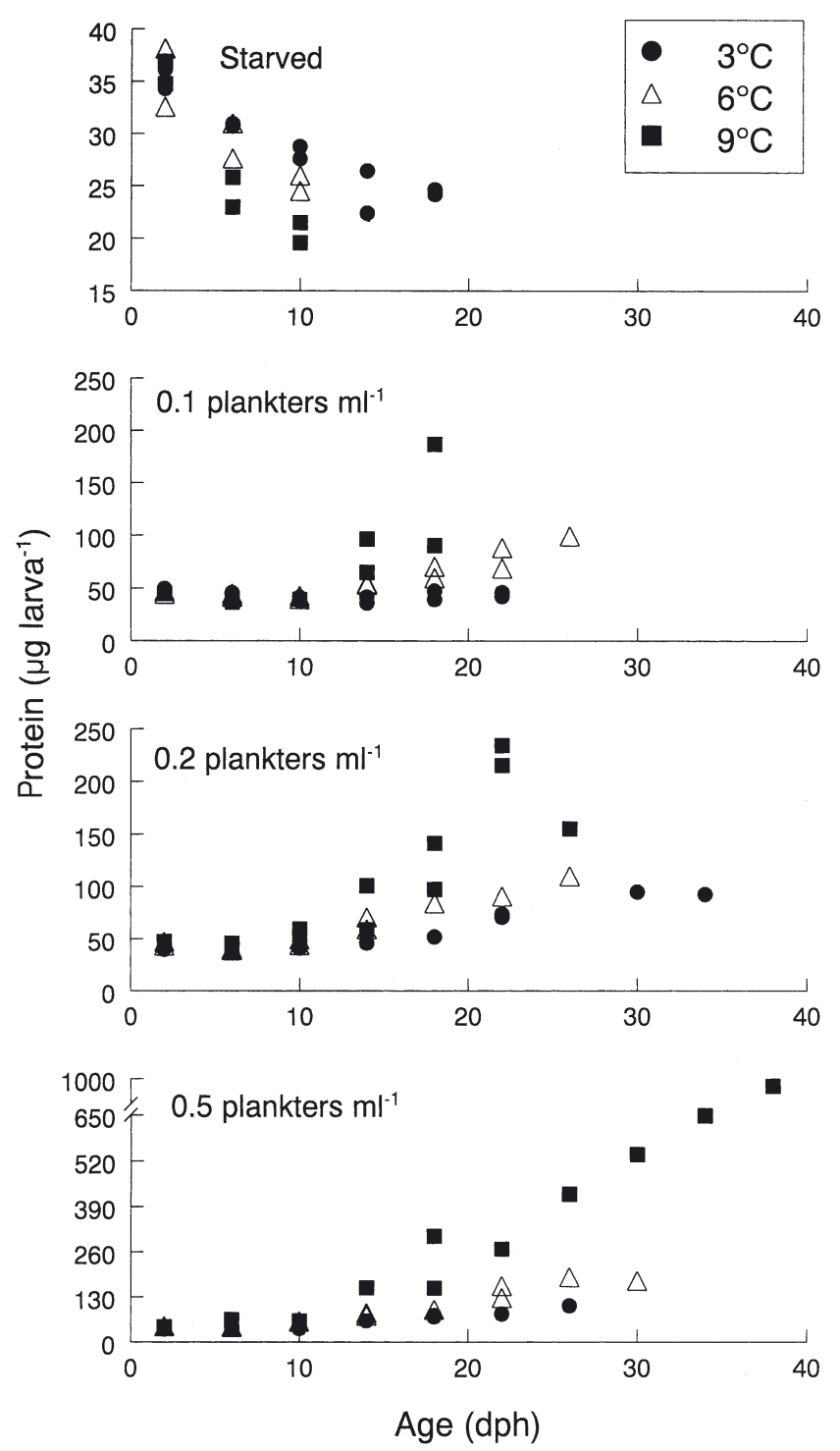

Fig. 1. Gadus morhua. Age-specific protein content $(\mu \mathrm{g}$ larva $^{-1}$ ) of cod larvae at each combination of prey concentration and temperature. Each data point represents a sample (tank) mean ( $\mathrm{n}=3$ to 10 larvae). Data are from starved and wild-plankton-fed fish. dph: days posthatch and $10 \mathrm{dph}$ at 3,6 , and $9^{\circ} \mathrm{C}$ respectively, with minimum R/D levels of 1.8, 1.9 and 1.4 respectively. Growth rates of the fish during this time were negative or near zero (Fig. 5).

Over the course of the trial, the mean DNA content of the majority of the fed fish increased with increasing age and temperature at all 3 wild-plankton densities (Fig. 2). At the 2 lower prey densities, mean RNA content initially decreased slightly, while larvae in the highest prey density group exhibited a slight increase (Fig. 3). The RNA content of all fed groups then generally increased with increasing age and temperature. These changes in RNA and DNA content resulted in an initial decrease in R/D at the 2 lower food densities to a
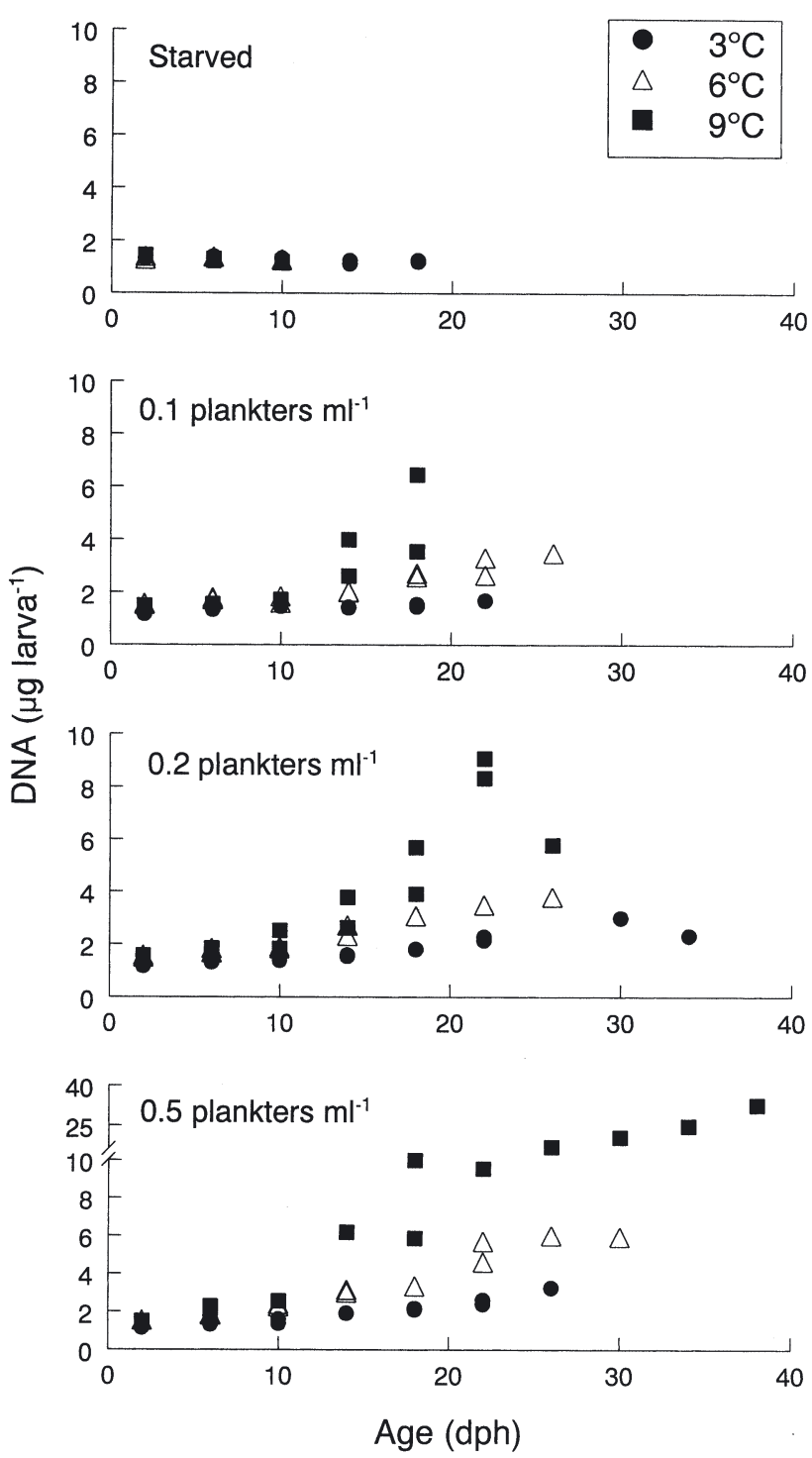

Fig. 2. Gadus morhua. Age-specific DNA content ( $\left.\mu g \operatorname{larva}^{-1}\right)$ of cod larvae at each combination of prey concentration and temperature. Nucleic acid values were determined with flowinjection fluorometric assay (FIA). Further details as in Fig. 1 
minimum level which coincided with the timing of $100 \%$ mortality in the starved groups at each respective temperature (Fig. 4). The R/D of the survivors then generally increased for the remainder of the experiment. Fish offered 0.5 plankters $\mathrm{ml}^{-1}$ had smaller decreases in R/D during the first 6 to $10 \mathrm{dph}$, followed by an increase (Fig. 4). Mean initial growth rates of the fed fish, especially at the 2 lower food densities and temperatures, were poor and similar to those of the starved fish. Growth rates of the survivors then generally increased with increasing age, followed by a leveling off or decline (Fig. 5).

Similar trends were observed in the rotifer-fed fish. Mean length, protein and DNA content of the larvae increased with increasing age and temperature, while RNA content and R/D initially decreased to a minimum
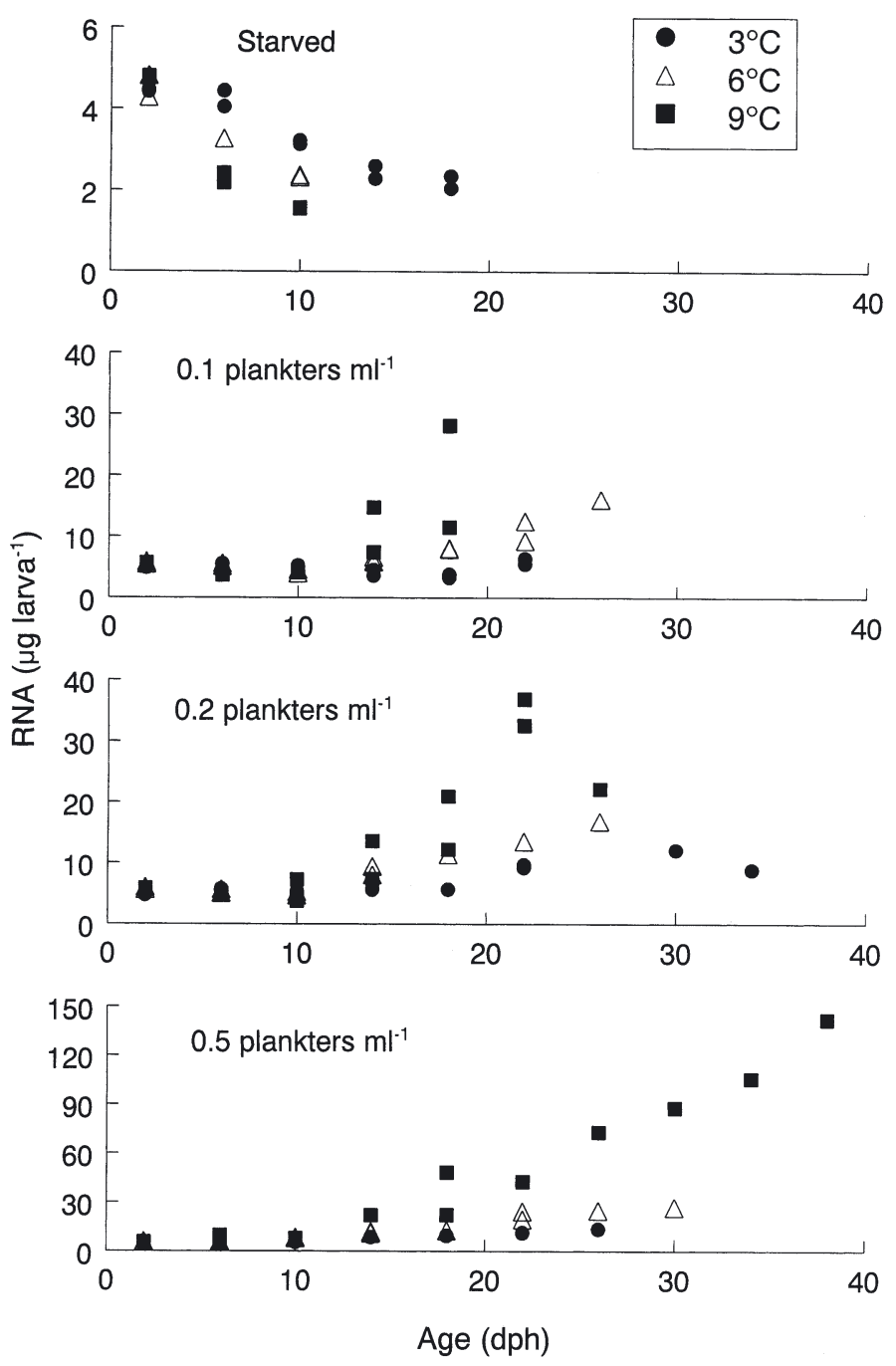

Fig. 3. Gadus morhua. Age-specific RNA content ( $\mu$ g larva ${ }^{-1}$ ) of cod larvae at each combination of prey concentration and temperature. Nucleic acid values were determined with FIA assay. Further details as in Fig. 1
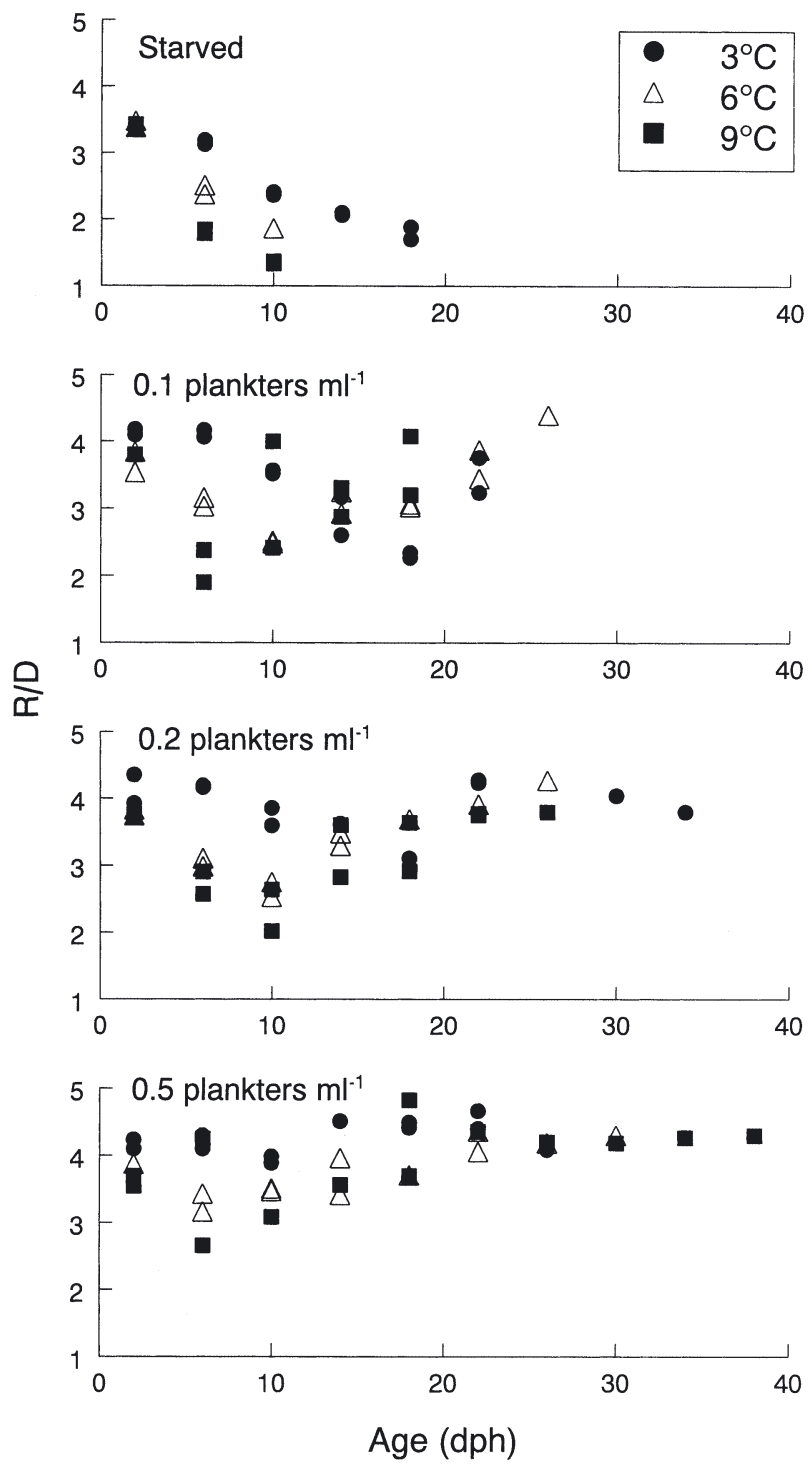

Fig. 4. Gadus morhua. Age-specific RNA/DNA ratio (R/D) of cod larvae at each combination of prey concentration and temperature. Nucleic acid values were determined with the FIA assay. Further details as in Fig. 1

level at approximately 18, 10 and 6 dph at 3, 6, and $9^{\circ} \mathrm{C}$, generally coinciding with the timing of $100 \%$ mortality in the corresponding starved groups. RNA content and R/D of the survivors then generally increased for the remainder of the experiment. All of the larvae with the exception of those fed 4 rotifers $\mathrm{ml}^{-1}$ at 3 and $6^{\circ} \mathrm{C}$ reached their initial R/D levels by the conclusion of the experiment. Mean initial growth rates of the rotifer-fed fish, especially at the 2 lower temperatures, were poor and similar to those of the starved fish. Growth rates of the survivors then generally increased with increasing age, followed by a leveling off or decline. 

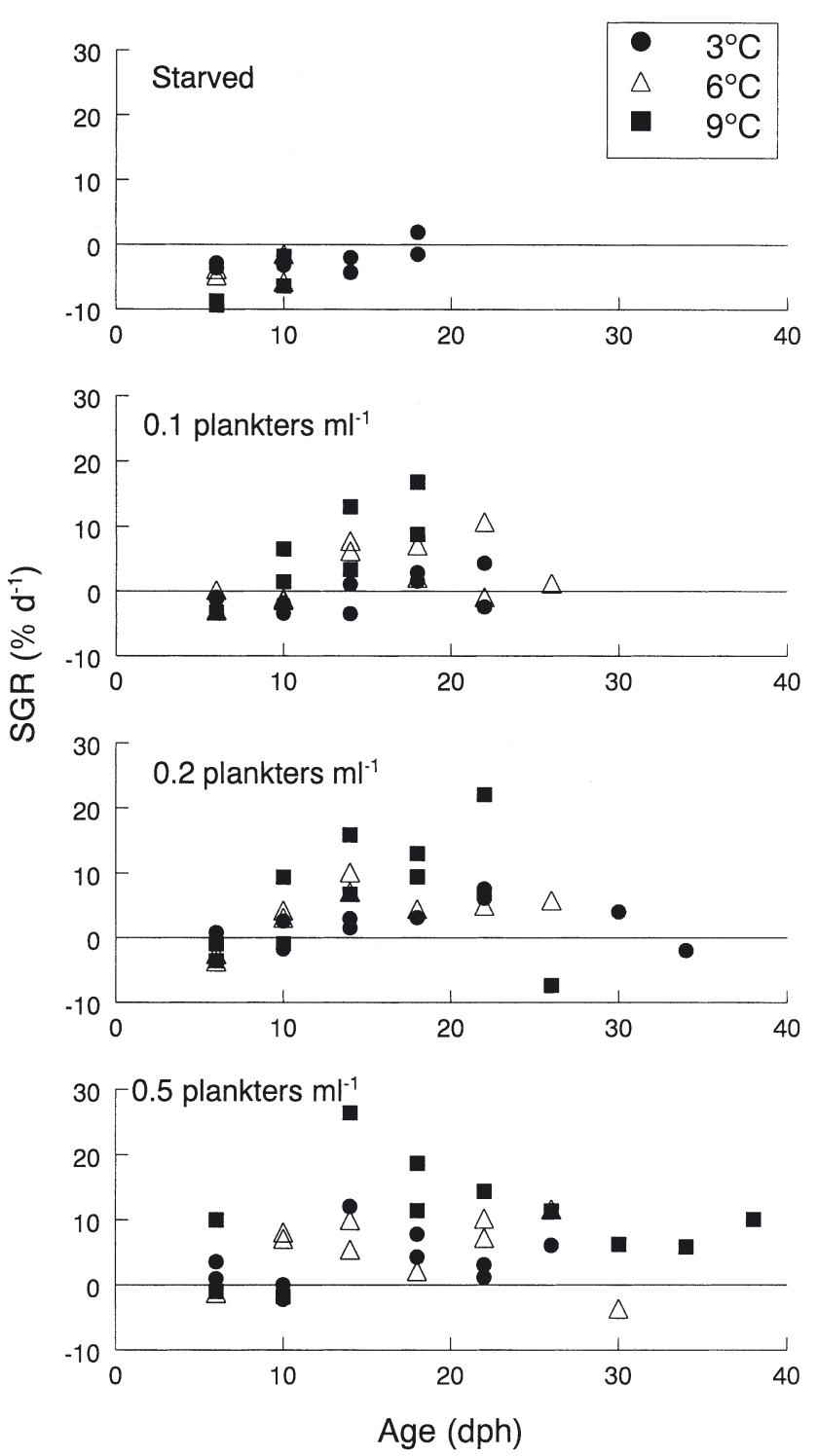

Fig. 5. Gadus morhua. Age-specific protein-specific growth rate (SGR) of cod larvae at each combination of prey concentration and temperature. Further details as in Fig. 1

\section{Model development}

A significant linear relationship was observed between SGR and temperature, and SGR and R/D (Table 3: Eqs. 1, 2, 6 \& 7). The inclusion of both these variables in the models significantly reduced the residual mean square statistically (Table 3: Eqs. 3 \& 8). The addition of any of the size-related variables as a third independent variable did not significantly improve the relationships statistically. An examination of plots of growth residuals (from Eqs. 3 \& 8) vs any of the sizerelated variables did not reveal any trends with size. When plotted against age, growth residuals from both equations were consistently negative (predicted growth higher than observed) for 6 dph larvae (SGR calculated over the interval 2 to $6 \mathrm{dph}$ ); therefore, only fish older than $6 \mathrm{dph}$ were included in the regressions. R/D and protein/DNA were positively correlated $(\mathrm{r}=0.69$ : Table 1). Substituting protein/DNA for R/D in the models yielded slightly lower $\mathrm{R}^{2}$ values (Table 3: Eqs. 5 $\& 10)$. Within a single rearing temperature, R/D alone could distinguish between fast- and slow-growing fish (Fig. 6). However, at constant protein growth rates, R/D and temperature were inversely related (Fig. 6, Table 3: Eqs. 3 \& 8).

\section{DISCUSSION}

\section{Methodology}

The microplate fluorometric assay (MFA) proved to be a sensitive reliable technique with a more rapid daily output of samples and smaller sample-size requirement $(16 \times$ smaller $)$ than the flow-injection analysis assay (FIA). The smaller sample for MFA permits multiple analyses of a single larva which is not possible with the FIA system. In addition, FIA systems are composed of an assemblage of components such as autosamplers, switching valves, and flow-through fluorometers which tend to be vulnerable to air-bubble entrapment. Because the MFA utilizes a 96-well format, it is more easily transportable for use on board research vessels. We have successfully used the MFA at sea, obtaining near real-time ( $6 \mathrm{~h}$ lag) estimates of larval RNA and DNA content and growth rates. Estimates of real-time growth rates in the field would allow researchers to adjust their cruise plan to optimize sampling strategies.

\section{Larval growth rates}

In this study, time-averaged mean SGRs of cod larvae fed different ration levels of wild plankton or rotifers at 3,6 , and $9^{\circ} \mathrm{C}$ ranged between -7.6 and $13.3 \% \mathrm{~d}^{-1}$ (Table 2). These values are comparable to others reported in the literature. For example, cod larvae fed 2 to 3 wild plankters $\mathrm{ml}^{-1}$ at 4,7 , and $10^{\circ} \mathrm{C}$ grew at $4.2,6.7$ and $8.8 \% \mathrm{~d}^{-1}$ respectively; when fed a range of prey levels $\left(0.2\right.$ to 3 plankters $\mathrm{ml}^{-1}$ ) at $7^{\circ} \mathrm{C}$, SGRs were 0.03 to $6.5 \% \mathrm{~d}^{-1}$ (Laurence 1978, Laurence et al. 1981). In another study, larval cod fed different ration levels of rotifers and Artemia sp. nauplii at 7 to $9^{\circ} \mathrm{C}$ had mean SGRs of 4.5 to $8.0 \% \mathrm{~d}^{-1}$ (Gotceitas et al. 1996). Otterlei et al. (1999), using a longer photoperiod (19 h) and maximum rations, reported larval cod mean growth values of $5.0,10.5$ and $15.2 \% \mathrm{~d}^{-1}$ at 3,6 , and $9^{\circ} \mathrm{C}$ respectively. 
Table 3. Gadus morhua. Equations for growth of cod larvae using data from plankton-fed, rotifer-fed, and starved larvae combined. Equations contain only variables that significantly improved model $\mathrm{R}^{2}$ value. Either protein-specific growth rate (SGR, \% $\left.\mathrm{d}^{-1}\right)$ or instantaneous growth coefficient $\left(G_{i} \mathrm{~d}^{-1}\right)$ is the dependent variable; R/D, protein/DNA, and temperature are independent variables. Equations based on 2 fluorometric methods for analysis of nucleic acids (FIA and MFA) are shown. Input values are tank means of measured parameters from an individual sampling day, mean tank temperature between sampling days, and corresponding SGR or $G_{i}$. All regressions are significant at the $\mathrm{p}<0.0001$ level

\begin{tabular}{|c|c|c|c|c|c|c|}
\hline $\begin{array}{l}\text { Analytical method } \\
\text { Eq. no. }\end{array}$ & $y$ & $x_{1}$ & $x_{2}$ & Equation & $\mathrm{R}^{2}$ & $\mathrm{n}$ \\
\hline \multicolumn{7}{|c|}{ Flow-injection fluorometric assay (FIA) } \\
\hline 1 & SGR & Temperature & & $y=1.17 x_{1}-2.47$ & 0.21 & 140 \\
\hline 2 & SGR & $\mathrm{R} / \mathrm{D}$ & & $y=4.15 x_{1}-8.41$ & 0.23 & 140 \\
\hline 3 & SGR & $\mathrm{R} / \mathrm{D}$ & Temperature & $y=3.65 x_{1}+1.02 x_{2}-13.05$ & 0.39 & 140 \\
\hline 4 & $G_{i}$ & $\mathrm{R} / \mathrm{D}$ & Temperature & $y=0.035 x_{1}+0.009 x_{2}-0.124$ & 0.39 & 140 \\
\hline 5 & SGR & Protein/DNA & Temperature & $y=0.63 x_{1}+1.20 x_{2}-18.83$ & 0.33 & 140 \\
\hline \multicolumn{7}{|c|}{ Microplate fluorometric assay (MFA) } \\
\hline 6 & SGR & Temperature & & $y=1.08 x_{1}-1.78$ & 0.18 & 128 \\
\hline 7 & SGR & $\mathrm{R} / \mathrm{D}$ & & $y=4.62 x_{1}-7.22$ & 0.25 & 128 \\
\hline 8 & SGR & $\mathrm{R} / \mathrm{D}$ & Temperature & $y=4.03 x_{1}+0.88 x_{2}-11.16$ & 0.37 & 128 \\
\hline 9 & $G_{i}$ & $\mathrm{R} / \mathrm{D}$ & Temperature & $y=0.039 x_{1}+0.008 x_{2}-0.107$ & 0.37 & 128 \\
\hline 10 & SGR & Protein/DNA & Temperature & $y=0.74 x_{1}+0.94 x_{2}-17.64$ & 0.34 & 128 \\
\hline
\end{tabular}

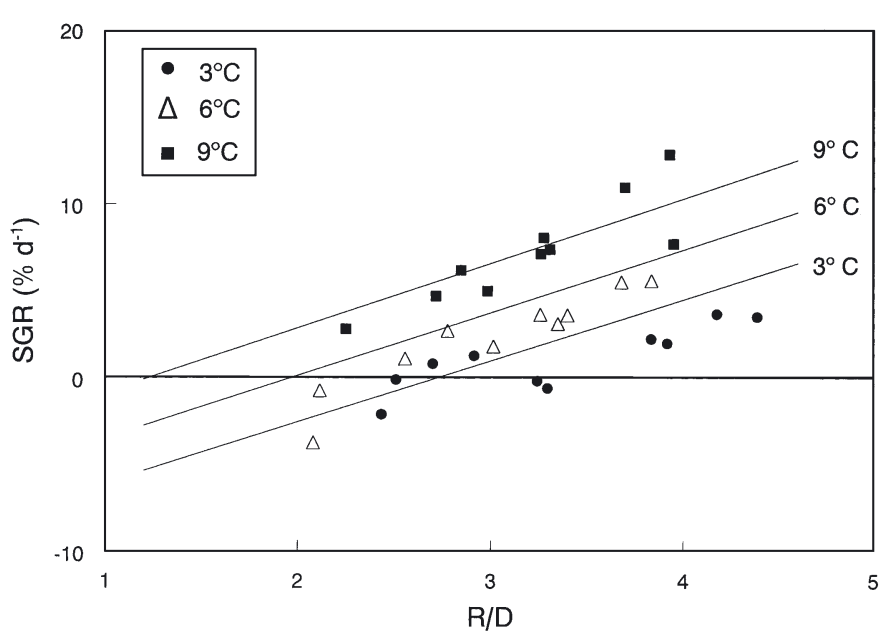

Fig. 6. Gadus morhua. Relationship at each rearing temperature between time-averaged tank mean R/D and proteinspecific growth rate (SGR) of cod larvae. Symbols represent the mean of 4 to 9 tank means. Data are from wild-plankton fed and rotifer-fed fish combined. Nucleic acid values were determined with FIA assay. Illustrated regression lines were obtained by inputting R/D and either 3,6 , or $9^{\circ} \mathrm{C}$ into FIA model equation (Eq. 3, $\mathrm{n}=140$ )

In the present study, we chose the levels of wildplankton prey to produce larvae with a large range of growth rates based upon a larval cod study by Buckley et al. (1993). The rotifer prey levels were chosen to provide energy comparable to the wild-plankton prey levels. The average energy content of an individual copepod nauplii, copepodite, and adult is approximately $1.6 \times, 11.4 \times$, and $112 \times$ respectively the average energy content of a rotifer (Holm et al. 1991). In the present study, the wild plankton diet resulted in higher cod growth-rates than the rotifer diet (Table 2). The observed differences could be due to the quality or quantity of prey provided, or differences between prey-type/temperature interactions. At 3 and $6^{\circ} \mathrm{C}$, the rotifers resided in the lower third of the water column while the wild plankton remained suspended throughout the water column, possibly increasing encounter rates with the larvae.

In this study, at almost all combinations of temperature and prey concentration, larval cod R/D decreased after hatch. During this same time period, growth rates were also low (Fig. 5). This decrease in R/D and low growth rate in early yolk-sac larvae has also been observed in laboratory studies with herring Clupea harengus (Clemmesen 1987) and red drum Sciaenops ocellatus, (Westerman \& Holt 1994). Puvanendran \& Brown (1999) reported that cod larvae reared at $8^{\circ} \mathrm{C}$ and 7 feeding levels exhibited a decrease in SGR between 7 and $14 \mathrm{dph}$ with a return to initial levels by $21 \mathrm{dph}$. When reared at 7 to $9^{\circ} \mathrm{C}$, cod larvae begin to feed at 4 to $7 \mathrm{dph}$ (Buckley 1979, Yin \& Blaxter 1986, Gotceitas et al. 1996), with near-complete absorption of yolk-sac observed by 14 to $18 \mathrm{dph}, 13 \mathrm{dph}$ and 10 to $17 \mathrm{dph}$ at $5,6.9$, and $10^{\circ} \mathrm{C}$ respectively (Yin \& Blaxter 1986, Hunt von Herbing et al. 1996). The 'point of no return' for cod larvae, when no food is available, is reached at 11 to $18 \mathrm{dph}$ (Yin \& Blaxter 1986, Gotceitas et al. 1996). The minimum levels of R/D and growth rates in the fed treatments in this study coincided with the timing of near complete exhaustion of the yolk-sac and the point of no return, and the sampling period when the last of the starved fish died $(18,10$ and $10 \mathrm{dph}$ 
at $3,6,9^{\circ} \mathrm{C}$ respectively). The subsequent increase in $\mathrm{R} / \mathrm{D}$ and growth rate in the fed treatments is most likely due to a combination of the completion of the die-off of weaker larvae which were unable to initiate feeding, coupled with the successful establishment of exogenous feeding on the part of the survivors.

\section{Model results}

Of the variables measured, R/D explained the highest proportion of variability in observed growth $\left(\mathrm{R}^{2}=0.23\right.$ and 0.26 , FIA and MFA respectively). Adding temperature as a second independent variable resulted in a statistically significant increase in the $\mathrm{R}^{2}$ value $\left(\mathrm{R}^{2}=0.39\right.$ and 0.37 , FIA and MFA respectively). Folkvord et al. (1996), studying population growth rates of herring larvae reared in mesocosms, determined that $70 \%$ of the observed variance in growth rate was explained with a model containing R/D and temperature as the independent variables. Buckley had seen similar relations with R/D, temperature and growth rates in laboratory-reared larval winter flounder (Buckley 1982, $\mathrm{R}^{2}=0.72$ ) and sand lance (Buckley et al. 1984, $\mathrm{R}^{2}=0.61$ ). The generalized R/D-temperature-growth equation he formulated using data from 8 temperate larval marine species explained $92 \%$ of the observed variance in growth rate (Buckley 1984). Since in all of these relationships, including those in this study, the slopes of both the R/D and temperature terms are positive, it follows that at a constant growth rate, temperature and R/D must be inversely related. Goolish et al. (1984), working with carp Cyprinus carpio, determined that, for a given growth rate, RNA concentration per unit tissue weight and per unit DNA was higher in colder-acclimated fish, and suggested that the elevated R/D levels observed at low temperatures was part of a mechanism that compensates for reduced RNA activity at low temperatures. Similar results and conclusions were observed with juvenile cod (Foster et al. 1992) and 1 yr old rainbow trout Oncorhynchus mykiss (Ferguson \& Danzmann 1990). In fed rainbow trout fry reared at 15 and $5^{\circ} \mathrm{C}$, RNA activity significantly decreased and protein turnover increased with decreasing temperature (Mathers et al. 1993). Within a narrow temperature range $\left(1\right.$ to $\left.2^{\circ} \mathrm{C}\right)$, R/D from individual larval fish can be directly compared and the relative nutritional condition of the fish inferred. For broader temperature ranges $\left(>2^{\circ} \mathrm{C}\right)$, the use of a growth model which includes both R/D and temperature terms is needed (Buckley et al. 1999).

The relationship among temperature, R/D, and growth did not appear to hold for the early yolk-sac larvae. Protein growth of these fish was consistently overestimated by the models, as evidenced by nega- tive residuals when plotted against age, and a decrease in the model $\mathrm{R}^{2}$. Therefore, all data for the 6 dph larvae (calculated over the interval 2 to $6 \mathrm{dph}$ ) were excluded from the final models. It is possible that, in the yolk-sac stage, RNA may not be as active, the net retention of protein may be reduced, or not all the protein produced is detected by the protein assay. Larval cod development is very rapid during the first week posthatch and includes marked skeletal changes in the morphology of the head, definition of the jaw and structure of the pectoral fins (Hunt von Herbing et al. 1996). A fibrous matrix of protein is a precursor to skeletal growth (Weatherley 1972). Possibly, a significant portion of proteins synthesized at this age is directed toward skeletal growth rather than soft-tissue growth. Since protein assays detect only those proteins that are solubilized during the extraction procedure, proteins incorporated into skeletal tissues may not be fully detected, resulting in an underestimation of the total protein content. When Folkvord et al. (1996) constructed growth models for herring using R/D, temperature, and size, they also excluded data collected during the first week of their experiment ( 0 to $7 \mathrm{dph}$ ) due to poor fit of their model. Results of the present study, and those of Folkvord et al. (1996), indicate that these models should be applied to yolk-sac/first-feeding larvae with caution.

As others have observed (Richard et al. 1991, Folkvord et al. 1996), standard length, weight, protein, RNA, and DNA content are all highly positively correlated during the larval period. Adding any of these size-related variables to the models in this study did not statistically significantly improve the model fit, and an examination of the residuals indicated no sizedependency in the relationship between R/D and growth. Data from some field and laboratory studies have shown no correlation between R/D and size (Buckley 1980, Buckley et al. 1984, Goolish et al. 1984, Malloy \& Targett 1994b, Lough et al. 1996, Chícharo et al. 1998, this study $\mathrm{R}^{2}=0.18$ ), while other studies have indicated a positive correlation (e.g. Canino et al. 1991, Folkvord et al. 1996, Rooker \& Holt 1996). The observed trends in R/D with size in the latter studies could be due to size-dependent mortality of smaller, weaker larvae resulting in a higher average R/D with an increase in age, or to a general increase in growth rate with age. As discussed in Buckley et al. (1999), the effect of incorporating size as a covariate to adjust mean R/D of treatment or site should be carefully considered before use.

Because different procedures for analyzing nucleic acids result in different estimates of RNA and DNA content, an intercalibration between methods is required prior to applying published R/D-temperature-growth models to larvae analyzed with differing 
methodologies (Grémare \& Vétion 1994, Canino \& Caldarone 1995, Caldarone et al. 2001). Alternatively, a specific model relating R/D, temperature, and growth can be calibrated with laboratory-reared larvae using the analytical method and standards of choice. We chose the second approach in part because the large minimum sample-size requirement of the Buckley UV-method ( 600 $\mu \mathrm{g}$ dry weight; Buckley \& Bulow 1987) precludes validation of a conversion factor for the smaller individuals. In the present study, $88 \%$ of the larvae were smaller than $600 \mu \mathrm{g}$ dry weight ( 9 mm length).

\section{Growth estimates}

Growth over short time intervals is difficult to estimate from serial measurements, since one is attempting to measure a small difference between 2 much larger numbers. Due to the destructive nature of sampling, protein values for an individual fish can only be measured once, and size at the beginning of the interval must be estimated from the mean of larvae sampled previously. In this study, growth between consecutive sampling days was estimated from the differences in mean protein content of the fish sampled. We found that using final protein values from individuals introduced more error into the models, most probably because the initial protein content of the individual varied considerably from the mean of larvae sampled previously. Within a treatment unit (single tank), individual larval growth was highly variable. For example, in the wild-plankton trial, fish $22 \mathrm{dph}$ from the 0.2 plankters $\mathrm{ml}^{-1}$ feeding treatment at $9^{\circ} \mathrm{C}$ had lengths ranging from 6 to $11 \mathrm{~mm}$. The R/D-temperature-growth models in this study explained 37 to $39 \%$ of the observed variability in growth, depending upon the fluorometric method used. It is likely that much of the error can be ascribed to error in the growth estimates. Although over 1360 individual fish were analyzed, the effective sampling size for calculating the means was small (3 to 10 fish per sampling interval). This sample size, along with large inter-individual variability and low growth, may have contributed to variability in mean growth-rate estimates. When the relationships were examined over a longer growth interval (8 d), the $R^{2}$ improved to $0.42-0.44$. The longer sampling interval most likely resulted in reduced error in the growth estimate due to a larger change in protein content. Although fluorometric assays allow for the analysis of individuals (a definite advantage for field studies), multiple samples each containing many individuals may provide a more accurate estimate of the average protein content for the purpose of calibrating growth models (as was done by Buckley 1982 and Buckley et al. 1984).

\section{Criteria for identification of starving yolk-sac/ first-feeding larvae}

Because the models do not accurately predict growth rates for yolk-sac/first-feeding larvae ( 2 to $6 \mathrm{dph}$ ), we wanted to develop criteria for identifying poor-condition larvae at this developmental stage. At hatch, larvae contain a yolk reserve that supplies energy and metabolites for further growth and development. In the absence of food, yolk-sac larvae can survive on their endogenous reserves for varying periods of time depending upon temperature. In this study, larvae at 3 , 6 and $9^{\circ} \mathrm{C}$ survived without food for a maximum of 18 , 10 and $10 \mathrm{dph}$ respectively. Net protein catabolism is an important energy source during this period. At hatch, the cod larvae contained between 22 and $54 \mu \mathrm{g}$ protein. Just before complete mortality, the protein content of the starved larvae had decreased by an average of 31,28 and $43 \%$ at the 3 temperatures respectively. At all 3 temperatures, $100 \%$ of the larvae sampled had R/D > 2.5 at $2 \mathrm{dph} ; 100 \%$ of the starved larvae had R/D $<2.5$ by 14,10 , and 6 dph at 3,6 and $9^{\circ} \mathrm{C}$ respectively, and the $\mathrm{R} / \mathrm{D}$ continued to decrease until complete mortality of the groups was reached. Based on these data, starving yolk-sac/first-feeding cod larvae can be identified as larvae containing $<50 \mu \mathrm{g}$ protein with R/D $<2.5$. The R/D cutoff was not adjusted for temperature. Larvae held at higher temperatures reached the cutoff after just 6 d without food, while larvae held at lower temperatures survived longer and reached the cutoff after $14 \mathrm{~d}$ without food.

\section{Alternative biochemical-based indicators of growth}

Protein/DNA is a relative index of cell size, which was found to be highly correlated with R/D in this study $(r=0.69)$ and in a study with larval red drum (Westerman \& Holt 1994). Substituting protein/DNA for R/D in our models (Table 3: Eqs. 5 \& 10) results in a lower $\mathrm{R}^{2}$ but has the potential to be a useful index of condition. One attribute of protein/DNA is that separate analytical procedures are used to obtain estimates of each parameter, which is not the case with R/D. Current fluorometric techniques employ sequential subtraction steps to obtain the individual nucleic acid concentrations; therefore any error in measurement of RNA may affect the measured concentration of DNA, and the total error may be magnified in the R/D. However, careful attention to procedural details will eliminate these potential problems. 
Acknowledgements. The authors would like to thank Steve Dornsife and Jennifer Allen-Guilmette for maintaining the cod broodstock, rearing rotifers and micro-algae, and assisting in the collection of wild plankton. We would also like to thank Mike Peck and Ashok Deshpande for reviewing an earlier draft of this manuscript. This work was supported by grants from the National Oceanic and Atmospheric Administration and the National Science Foundation. This is US GLOBEC contribution number 377.

\section{LITERATURE CITED}

Buckley LJ (1979) Relationships between RNA-DNA ratio, prey density, and growth rate in Atlantic cod (Gadus morhua) larvae. J Fish Res Board Can 36:1497-1502

Buckley LJ (1980) Changes in ribonucleic acid, deoxyribonucleic acid, and protein content during ontogenesis in winter flounder, Pseudopleuronectes americanus, and effect of starvation. Fish Bull US Dep Comm 77:703-708

Buckley LJ (1982) Effects of temperature on growth and biochemical composition of larval winter flounder Pseudopleuronectes americanus. Mar Ecol Prog Ser 8:181-186

Buckley LJ (1984) RNA/DNA ratio: an index of larval fish growth in the sea. Mar Biol 80:291-298

Buckley LJ, Bulow FJ (1987) Techniques for the estimation of RNA, DNA, and protein in fish. In: Summerfelt RC, Hall GE (eds) The age and growth of fish. Iowa State University Press, Ames, IA, p 345-354

Buckley LJ, Lough RG (1987) Recent growth, biochemical composition, and prey field of larval haddock (Melanogrammus aeglefinus) and Atlantic cod (Gadus morhua) on Georges Bank. Can J Fish Aquat Sci 44:14-25

Buckley LJ, Turner SI, Halavik TA, Smigielski AS, Drew SM, Laurence GC (1984) Effects of temperature and food availability on growth, survival, and RNA-DNA ratio of larval sand lance (Ammodytes americanus). Mar Ecol Prog Ser 15:91-97

Buckley LJ, Smigielski AS, Halavik TA, Burns BR, Laurence GC (1993) Growth and survival of the larvae of three temperate marine fish species at discrete prey densities. II. Cod (Gadus morhua), winter flounder (Pseudopleuronectes americanus), and silver hake (Merluccius bilinearis). In: Walther BT, Fyhn HJ (eds) Physiological and biochemical aspects of fish development. University of Bergen, Norway, p 183-195

Buckley L, Caldarone E, Ong TL (1999) RNA/DNA ratio and other nucleic acid-based indicators for growth and condition of marine fishes. Hydrobiologia 401:265-277

Buckley LJ, Bradley TM, Allen-Guilmette J (2000) Production, quality, and low temperature incubation of eggs of Atlantic cod Gadus morhua and haddock Melanogrammus aeglefinus in captivity. J World Aquacult Soc 31:22-29

Bulow FJ (1987) RNA-DNA ratios as indicators of growth in fish: a review. In: Summerfelt RC, Hall GE (eds) The age and growth of fish. Iowa State University Press, Ames, IA, p 45-64

Caldarone EM, Buckley LJ (1991) Quantitation of DNA and RNA in crude tissue extracts by flow injection analysis. Anal Biochem 199:137-141

Caldarone EM, Wagner M, St. Onge-Burns J, Buckley LJ (2001) Protocol and guide for estimating nucleic acids in larval fish using a fluorescence microplate reader. Ref Doc 01-11:1-22, National Marine Fisheries Service, Woods Hole, MA. Also available at www.nefsc.noaa.gov/nefsc/ publications/crd/crd0111/0111.htm

Canino MF, Caldarone EM (1995) Modification and compari- son of two fluorometric techniques for determining nucleic acid contents of fish larvae. Fish Bull US Dep Comm 93: 158-165

Canino MF, Bailey KM, Incze LS (1991) Temporal and geographic differences in feeding and nutritional condition of walleye pollock larvae Theragra chalcogramma in Shelikof Strait, Gulf of Alaska. Mar Ecol Prog Ser 79:27-35

Chícharo MA (1998) Nutritional condition and starvation in Sardina pilchardus (L.) larvae off southern Portugal compared with some environmental factors. J Exp Mar Biol Ecol 225:123-137

Chícharo MA, Chícharo L, Valdés L, López-Jamar E, Ré P (1998) Estimation of starvation and diel variation of the RNA/DNA ratios in field-caught Sardina pilchardus larvae off the north of Spain. Mar Ecol Prog Ser 164:273-283

Clemmesen CM (1987) Laboratory studies on RNA/DNA ratios of starved and fed herring (Clupea harengus) and turbot (Scophthalmus maximus) larvae. J Cons Int Explor Mer 43:122-128

Clemmesen C, Sanchez R, Wongtschowski C (1997) A regional comparison of the nutritional condition of SW Atlantic anchovy larvae, Engraulis anchoita, based on RNA/DNA ratios. Arch Fish Mar Res 45:17-43

Ferguson M, Danzmann R (1990) RNA/DNA ratios in white muscle as estimates of growth in rainbow trout held at different temperatures. Can J Zool 68:1494-1498

Folkvord A, Ystanes L, Johannessen A, Moksness E (1996) RNA:DNA ratios and growth of herring (Clupea harengus) larvae reared in mesocosms. Mar Biol 126:591-602

Foster AR, Houlihan DF, Hall SJ, Burren LJ (1992) The effects of temperature acclimation on protein synthesis rates and nucleic acid content of juvenile cod (Gadus morhua L.). Can J Zool 70:2095-2102

Goolish EM, Barron MG, Adelman IR (1984) Thermoclimatory response of nucleic acid and protein content of carp muscle tissue: influence of growth rate and relationship to glycine uptake by scales. Can J Zool 62:2164-2170

Gotceitas V, Puvanendran V, Leader LL, Brown JA (1996) An experimental investigation of the 'match/mismatch' hypothesis using larval Atlantic cod. Mar Ecol Prog Ser 130:29-37

Grémare A, Vétion G (1994) Comparison of several spectrofluorometric methods for measuring RNA and DNA concentrations in the deposit-feeding bivalve Abra ovata. Comp Biochem Physiol B107:297-308

Henshaw EC, Hirsch CA, Morton BE, Hiatt HH (1971) Control of protein synthesis in mammalian tissues through changes in ribosome activity. J Biol Chem 246:436-446

Heyer CJ, Miller TJ, Binkowski FP, Caldarone EM, Rice JA (2001) Maternal effects as a recruitment mechanism in Lake Michigan yellow perch (Perca flavescens). Can J Fish Aquat Sci 58:1477-1487

Holm JC, Svaasand T, Wennevik V (1991) Handbook of cod culture. Brood stock and fry production. Institute of Marine Research, Bergen

Houde ED (1987) Fish early life dynamics and recruitment variability. Am Fish Soc Symp 2:17-29

Houde ED, Schekter RC (1981) Growth rates, rations and cohort consumption of marine fish larvae in relation to prey concentrations. Rapp P-V Réun Cons Int Explor Mer 178:441-453

Hunt von Herbing I, Boutilier RG, Miyake T, Hall BK (1996) Effects of temperature on morphological landmarks critical to growth and survival in larval Atlantic cod (Gadus morhua). Mar Biol 124:593-606

Laurence GC (1978) Comparative growth, respiration and delayed feeding abilities of larval cod (Gadus morhua) and 
haddock (Melanogrammus aeglefinus) as influenced by temperature during laboratory studies. Mar Biol 50:1-7 Laurence GC, Smigielski AS, Halavik TA, Burns BR (1981) Implications of direct competition between larval cod (Gadus morhua) and haddock (Melanogrammus aeglefinus) in laboratory growth and survival studies at different food densities. Rapp P-V Réun Cons Int Explor Mer 178: 304-311

Lough RG, Caldarone EM, Rotunno TK, Broughton EA, Burns BR, Buckley LJ (1996) Vertical distribution of cod and haddock eggs and larvae, feeding and condition in stratified and mixed waters on southern Georges Bank, May 1992. Deep-Sea Res Part II 43:1875-1904

Malloy KD, Targett TE (1994a) Effects of ration limitation and low temperature on growth, biochemical condition, and survival of juvenile summer flounder from two Atlantic coast nurseries. Trans Am Fish Soc 123:182-193

Malloy KD, Targett TE (1994b) The use of RNA:DNA ratios to predict growth limitation of juvenile summer flounder (Paralichthys dentatus) from Delaware and North Carolina estuaries. Mar Biol 118:367-375

Mathers EM, Houlihan DF, McCarthy ID, Burren LJ (1993) Rates of growth and protein synthesis correlated with nucleic acid content in fry of rainbow trout, Oncorhynchus mykiss: effects of age and temperature. J Fish Biol 43: 245-263

Meekan MG, Fortier L (1996) Selection for fast growth during the larval life of Atlantic cod Gadus morhua on the Scotian Shelf. Mar Ecol Prog Ser 137:25-37

Otterlei E, Nyhammer G, Folkvord A, Stefansson SO (1999) Temperature- and size-dependent growth of larval and early juvenile Atlantic cod (Gadus morhua): a comparative study of Norwegian coastal cod and northeast Arctic cod. Can J Fish Aquat Sci 56:2099-2111

Puvanendran V, Brown JA (1999) Foraging, growth and survival of Atlantic cod larvae reared in different prey concentrations. Aquaculture 175:77-92

Editorial responsibility: Kenneth Sherman (Contributing Editor), Narragansett, Rhode Island, USA
Richard P, Bergeron JP, Boulhic M, Galois R, Person-Le Ruyet J (1991) Effect of starvation on RNA, DNA and protein content of laboratory-reared larvae and juveniles of Solea solea. Mar Ecol Prog Ser 72:69-77

Robinson SMC, Ware DM (1988) Ontogenetic development of growth rates in larval Pacific herring, Clupea harengus pallasi, measured with RNA/DNA ratios in the Strait of Georgia British Columbia. Can J Fish Aquat Sci 45: $1422-1429$

Rooker JR, Holt GJ (1996) Application of RNA:DNA ratios to evaluate the condition and growth of larval and juvenile red drum (Sciaenops ocellatus). Mar Freshw Res 47: $283-290$

Rooker JR, Holt GJ, Holt SA (1997) Condition of larval and juvenile red drum (Sciaenops ocellatus) from estuarine nursery habitats. Mar Biol 127:387-394

SAS Institute (1999) SAS/STAT user's guide, Version 6, 4th edn, Vol 2. SAS Institute, Cary, NC

Smith PK, Krohn RI, Hermanson GT, Mallia AK and 6 others (1985) Measurement of protein using bicinchoninic acid. Anal Biochem 150:76-85

Weatherley AH (1972) Growth and ecology of fish populations. Academic Press, London

Westerman M, Holt GJ (1994) RNA:DNA ratio during the critical period and early larval growth of the red drum Sciaenops ocellatus. Mar Biol 121:1-9

Wright DA, Martin FD (1985) The effect of starvation on RNA:DNA ratios and growth of larval striped bass, Morone saxatalis. J Fish Biol 27:479-485

Yin MC, Blaxter JHS (1986) Morphological changes during growth and starvation of larval cod (Gadus morhua L.) and flounder (Platichthys flesus L.). J Exp Mar Biol Ecol 104: 215-228

Young VR (1970) The role of skeletal and cardiac muscle in the regulation of protein metabolism. In: Munro HN (ed) Mammalian protein metabolism. Academic Press, London, p 585-674

Submitted: January 23, 2003; Accepted: June 23, 2003

Proofs received from author(s): October 29, 2003 